received the gold medal in the Red Cross publicity and promotion subsection.

The ICRC, League, Bulgarian and Hungarian Red Cross co-production "What's in a symbol", by the Hungarian producer, Georges Karpati, had its world premier at the opening of the festival with several thousand spectators. The film was very well received. Upon the decision of the President of the ICRC and the President of the League, it did not take part in the festival competition. It is available in the official languages of the International Red Cross at the League or at the ICRC.

As before, the Tenth International Festival in Varna was a great success. The International Review congratulates the Bulgarian Red Cross for this event and wishes it all the best in the future.

\title{
In Costa Rica
}

\section{Twelfth Inter-American Red Cross Conference}

The Twelfth Inter-American Red Cross Conference was held from 3 to 8 July in San José, Costa Rica. Organized by the Costa Rican Red Cross and the League, the Conference was attended by delegations from 23 National Societies, most of which were headed by their President; furthermore, seven National Societies from other continents were invited to attend as observers. The President of the League of Red Cross Societies, Mr. E. de la Mata, and the Secretary General, Mr. Hans Hoegh, led a delegation from the League. The ICRC was represented by its President, Mr. Alexandre Hay, and a large delegation.

The main purpose of the Conference was to examine the progress made under the Five-Year Development Plan of the Red Cross in America, adopted in Rio de Janeiro in 1979. The Conference would then decide whether to uphold the objectives of the plan and extend its duration, or whether to adopt new objectives and a new schedule.

To facilitate its work, the Conference was divided into six Commissions: general matters, assistance, health and social affairs, youth, dissemination and protection, social communication and public relations. The work was conducted in a very forthcoming atmosphere of constructive discussion.

The National Societies which had recently experienced and had to intervene in a situation of conflict expressed their viewpoints, explaining their roles and activities. They all stated how greatly they valued the 
ICRC's work in such situations of conflict, pointed out that the activities of the National Societies and those of the ICRC complement each other, and stressed the fact that the ICRC remains the only organization able to carry out certain protection activities in its capacity as a neutral intermediary.

The Conference then adopted a resolution (Resolution 1 ), in which, "deeply concerned by the armed conflicts and disturbances in Central America; particularly moved by the plight of the civilian population...; it recalls that humanitarian principles and the provisions of the Geneva Conventions must be respected by all and at all times, even in internal conflicts; it appeals to the parties to the conflicts to facilitate at all times the strictly humanitarian and neutral activities of the International Committee of the Red Cross and the Red Cross Societies of various countries; and it requests that the Red Cross be given every facility, including that of a local ceasefire, to enable it to offer protection and assistance without discrimination to all the victims". ${ }^{1}$

Further, during the Conference, the National Societies of El Salvador and Honduras each signed a bilateral agreement with the Nordic Red Cross Societies (of Denmark, Finland, Iceland, Norway and Sweden) to co-operate in the development of the operational set-up in the two American Societies. These agreements were countersigned by the ICRC and the League.

\footnotetext{
1 Provisional translation by the ICRC.
} 